\title{
Anti-crisis approach in the industrial enterprise management: methodological tools of preventive regulation
}

\author{
Olga Maslak $^{1 *}$, Petro Sokurenko ${ }^{2}$, Natalya Grishko ${ }^{1}$, Ievgen Buriak ${ }^{1}$, Mariya Maslak ${ }^{3}$ \\ ${ }^{1}$ Kremenchuk Mykhailo Ostrohradskyi National University, Pershotravneva Street 20, 39600 \\ Kremenchuk, Ukraine \\ ${ }^{2}$ Kremenchuk institute of Higher Educational Establishment «Alfred Nobel University», Naberezhna \\ Sicheslavska str. 18, 49000 Dnipro, Ukraine \\ ${ }^{3}$ National Technical University «Kharkiv Polytechnic Institute», Kyrpychova str. 2, 61002 Kharkiv, \\ Ukraine
}

\begin{abstract}
The paper covers the theoretical and methodological framework for assessment of the crisis management effectiveness and the enterprise bankruptcy probability. At the present stage of the Ukrainian economic development, the main weaknesses in the activities of enterprises include: loss of sales markets, imperfect production and sales policy, lack of working capital, inefficient financial management, significant production costs, which produce signs of crisis processes and determine the feasibility of preventive approach anti-crisis management use. At the same time, the choice of the topic is due to insufficient research of this scientific problem as a whole and its relevance for the economy of Ukraine, especially in the context of the search for external investment resources, cooperation on this basis with the European Union.

It was determined that one of the ways to solve the problem of predicting the probability of bankruptcy is the use of insolvency prediction models developed on the basis of the discriminant analysis method - Zcoefficients. The authors systematized the most well-known approaches to predicting the likelihood of bankruptcy of industrial enterprises, illustrated their advantages and disadvantages, the mutual consistency of use.

It has been established that additional opportunities for monitoring the effectiveness of anti-crisis measures are created by a system of indicators characterizing the level of effectiveness of the anti-crisis management system. Evaluating the effectiveness of the anti-crisis program only on the basis of an analysis of relative indicators is not enough: during the global financial crisis, sometimes convincing indicators of efficiency are absolute indicators and a projected trend of their change.

As part of this study, attention is paid to the analytical levers of the crisis management mechanism, which are aimed at preventive regulation and localization of crisis processes in the enterprise, restoring the effectiveness of production and marketing activities.
\end{abstract}

Keywords: crisis, crisis management, model, preventive regulation, bankruptcy, profitability, loss ratio, solvency.

\footnotetext{
${ }^{*}$ Corresponding author: 2nata.grishko@gmail.com
} 


\section{Introduction}

The variability of the external environment, the need to apply new approaches to the stabilization of activities and the development of enterprises actualizes the issue of the anticrisis approach for managing business entities. The effectiveness of anti-crisis measures depends on the speed of the enterprise response to the appearance of crisis processes' signs, which makes it advisable to apply a preventive approach to management. The aggravation of crisis processes in the production sphere, their systemic nature and the absence of an effective diagnostic apparatus for determining the depth of crisis phenomena, the scale of the crisis and effective mechanisms of crisis management determine the feasibility of research in this field.

The search for effective models of crisis management, theoretical and methodological apparatus for studying the impact of crisis processes on the activities of enterprises are in the interests of both foreign and domestic scientists: Azarenkova, Piskunov and Goikhman [1], Aref'eva [2], Bradley and Cowdery [3], Bryan, Fernando and Tripathy [4], Dikan and Nazarenko [5], Elexa, Hvolkova and Knapkova [6], Tobback [7]. The achievements of scientists and practitioners in predicting the likelihood of bankruptcy of business entities are really deep and significant, at the same time, the features of anti-crisis management technologies in domestic enterprises, the applied aspects of the evaluation model application in the realities of the national economy are not sufficiently studied.

Thus, the study of existing approaches to assessing the effectiveness of crisis management of enterprises leads to the conclusion that among modern concepts [2, 4-7] there is no objective method that would allow to give an unambiguous quantitative assessment of it. This indicates the need to develop an integrated approach to assess the degree of crisis based on the systematization of its main components and the establishment of relationships between them.

\section{Data and Methods}

The aim of the study is to formulate methodological approaches to assessing the effectiveness of crisis management in the operation of an enterprise based on preventive regulation.

The solution for the assigned tasks was carried out using the following methods: theoretical generalization - to study and systematize theoretical approaches to the definition and justification of the problem studied; analysis and synthesis - to determine the object and subject of research; graphic; mathematical statistics - when establishing the dependence of the integral indicator of assessing the effectiveness of the crisis management system.

Information base selected materials of official publications of the State Statistics Committee, data of domestic and foreign scientific literature, data of primary reporting documentation of enterprises, annual financial and statistical reporting.

\section{Results}

\subsection{Current state and prerequisites of crisis management of Ukrainian industrial enterprises}

All of the above indicates the feasibility of conducting research on applied aspects and theoretical and methodological approaches to crisis management of an enterprise. For industrial enterprises, these issues are priorities given the leading role of industry in the 
structure of the national economy and the dual nature of crisis processes in industrial development, in particular. On the one hand, crises are destructive in nature, they bring destabilization to the life processes of economic entities, and on the other hand, progressive changes that are revolutionary in nature take the beginning of abrupt growth at the point of bifurcation against the background of the crisis process. Thus, the occurrence of crises is a natural process and a starting point for constructive changes in business processes. A number of scientists note the cyclical nature of the emergence and, along with the subjective, objective prerequisites of crisis processes, a certain nature of socio-economic systems.

The emergence of a market economy in Ukraine is associated with the deployment of crisis processes in the activities of many enterprises. The dynamics of industrial production indices indicate a negative trend of a gradual decrease in production volumes by enterprises in Ukraine in 2010-2015. During 2016-2018 production stabilization was observed as a result of the increased profitability of the operating activities of Ukrainian enterprises (Fig. 1).

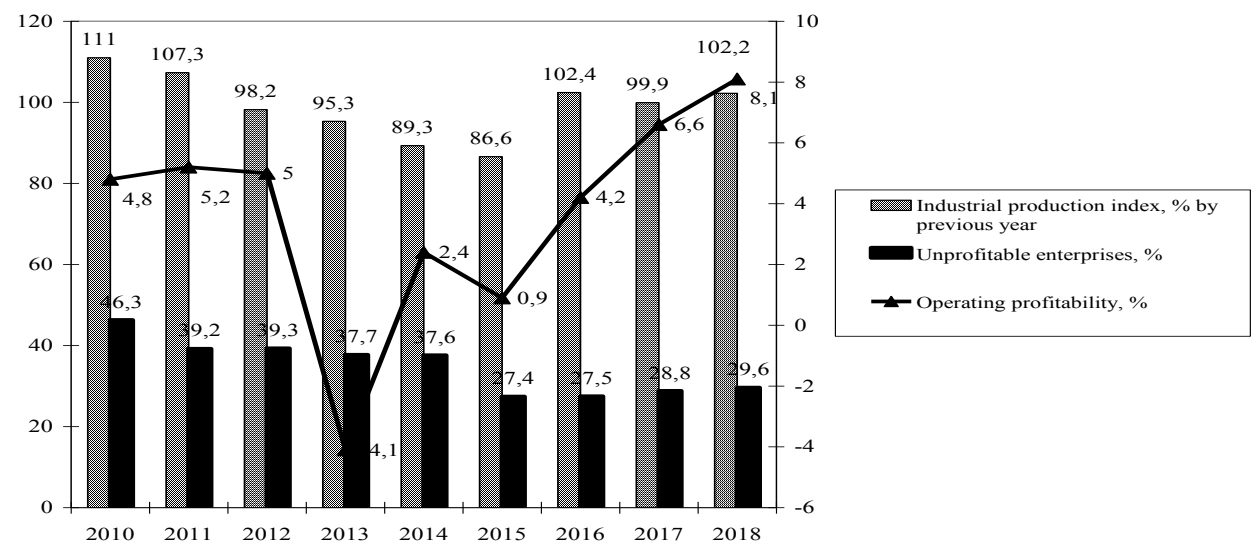

Fig. 1. Dynamics of indices of industrial production, unprofitable enterprises and profitability / unprofitability of operating activities of enterprises in Ukraine, \%

Source: Formed by the authors on the basis of [8].

The worst values of the profitability index (namely, a loss ratio of $4.1 \%$ ) were observed during 2013. At the end of the study period (January-August 2018), the profitability of operating activities increases to $8.1 \%$, which is the best value of this indicator during 2010 2018.

The study of unprofitability and bankruptcy of enterprises of Ukraine during 2010-2018 (January-August). Indicates a significant number of unprofitable enterprises - 27.4-46.3\% of the total. Despite a slight decrease (in 2014 - up to $37.6 \%$, and in 2015 - up to $27.4 \%$ ), the share of unprofitable enterprises in 2016 is still quite large. Since 2016, there has been a negative growth trend in the number of unprofitable enterprises, among the leading causes of this should be the influence of an unstable environment and inadequate actions of the enterprises themselves. Almost every 30 enterprises turned out to be unprofitable, with the load on the production capacities of industrial enterprises of Ukraine during 2014-2018. This indicates not a full measure of the use of the industrial sector potential.

Ukrainian large and medium-sized enterprises during the study period are characterized by non-utilization of production capacities, as a result, first of all, we get the lack of orders and a reduction in the demand for maintaining an excessive number of personnel, and, under these conditions, an increase in costs and a decrease in production profitability. At the same time, there was a negative irreversible upward trend in prices for raw materials 
and energy carriers, which also leads to an increase in expenditure aspects of the enterprises' s activities. The decrease in sales volumes and, consequently, profits, limits the financial development opportunities of enterprises, provokes financial insolvency and leads to a crisis state of enterprises.

The factors constraining production, based on materials from statistical studies, include: insufficient demand, lack of labor, lack of raw materials, materials, equipment, financial constraints. Negative financial results characterize, on the one hand, the crisis processes of the socio-economic system of an enterprise, on the other hand, the symptoms of a crisis are the appearance of signs of insolvency. All this limit the possibilities of self-financing of investment activities, as well as the development of the enterprise through research [9], of attracting external investment resources (Fig. 2).

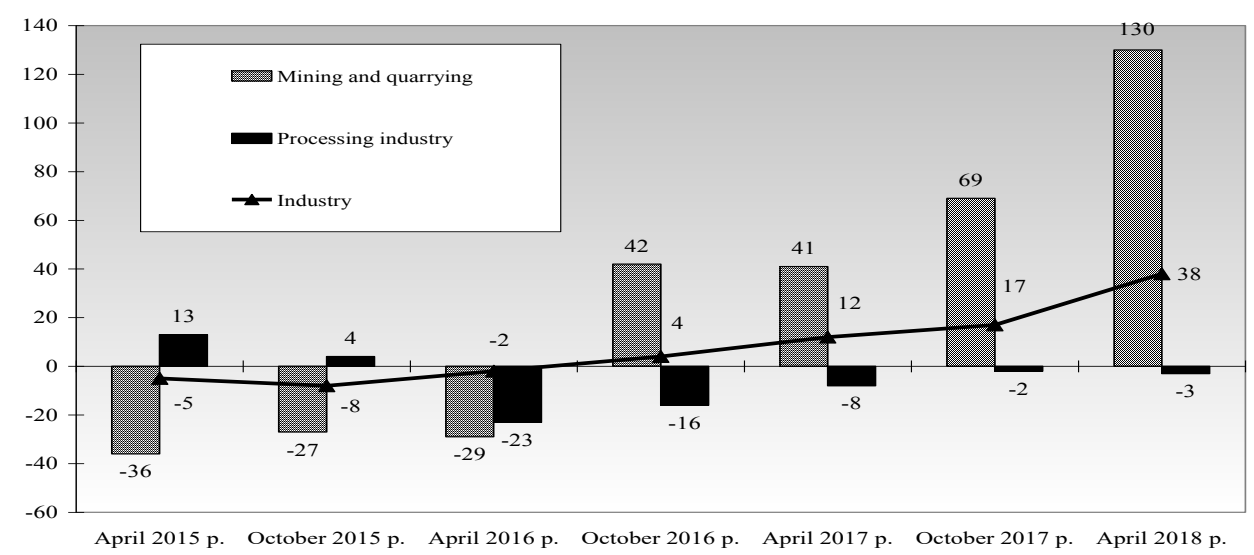

Fig. 2. Expected changes in the volume of capital investments of industrial enterprises of Ukraine in the current year compared with the previous year, \%

Source: Formed by the authors on the basis of [8].

The competitive position of industrial enterprises in foreign markets within the European Union in a certain way actualizes the issue of finding reserves to strengthen their position in the market [10-15] and the introduction of progressive changes in domestic enterprises, aims to increase their investment attractiveness (tab. 1).

Table 1. Evaluation of the competitive position of industrial enterprises in foreign markets within the European Union

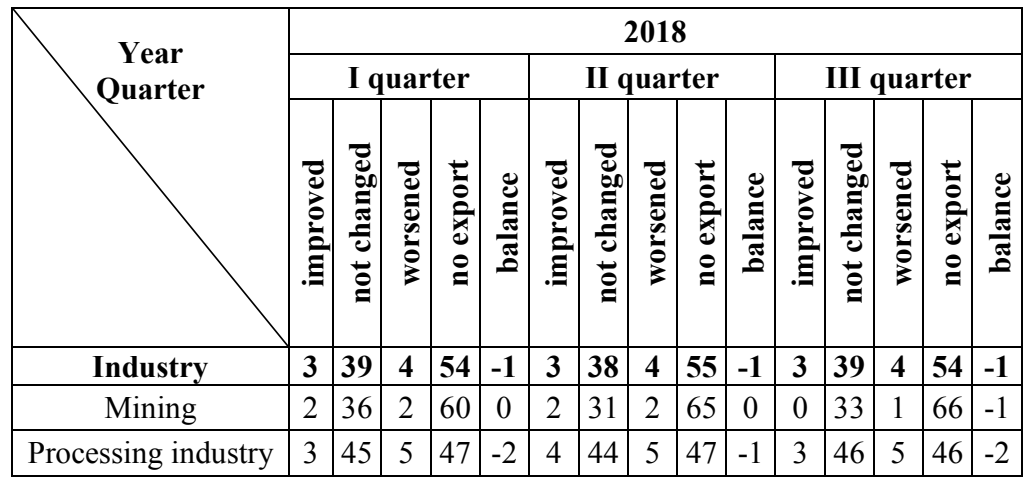

Source: Formed by the authors on the basis of [8]. 
The research results indicate potential opportunities for the indicator of business confidence of Ukrainian enterprises (Fig. 3), illustrate the positive dynamics, but at the same time, unfavorable development forecasts in the processing industry and in the industrial sector as a whole, actualize the issues of improving the crisis management system management for domestic enterprises.

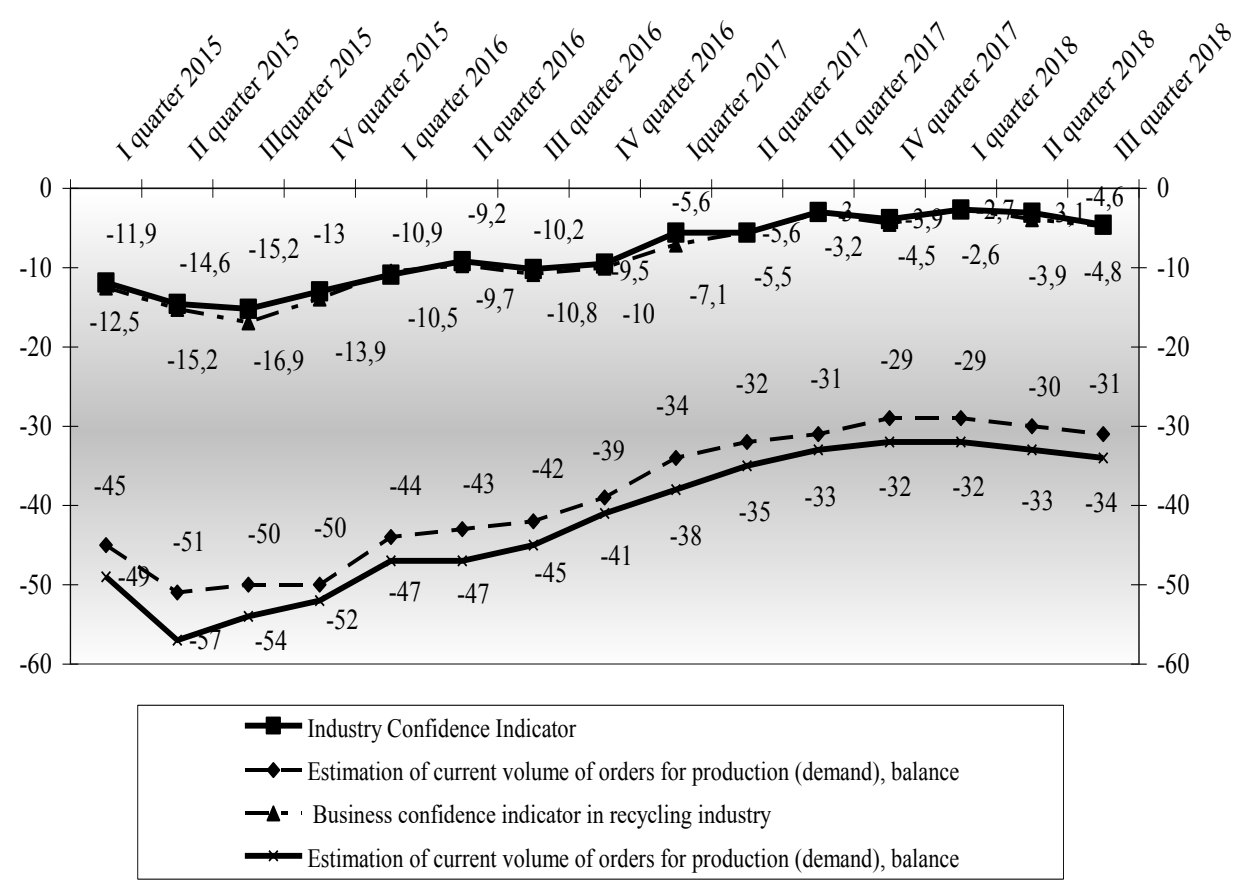

Fig. 3. Business confidence indicator in the industry of Ukraine (percent), \%

Source: Formed by the authors on the basis of [8].

So, the anti-crisis management of an industrial enterprise must be preventive in nature and, given the specificity of a particular object, be complex.

\subsection{Approaches to assessing the effectiveness of crisis management of the enterprise}

The company's activity in market conditions is associated with the risk of capital loss from inefficient management: as a result of large losses, an enterprise usually fails to settle its debt obligations, and, as a result, its crisis state and bankruptcy. To prevent the loss of invested funds, an analysis of the probability of bankruptcy is intended, the purpose of which is to provide interested persons with accurate and timely information about the possibility of occurrence, the scale of crisis phenomena and their consequences for developing measures to prevent or minimize their negative impact.

Research approaches to predicting the probability of bankruptcy, formed by foreign and domestic scientists [1-5], have, of course, a number of advantages. These include a relatively small number of estimated indicators, a complex character based on the formation, the possibility of obtaining a quantitative assessment. At the same time, the formation of models based on a statistical sample of foreign enterprises limits the possibility of obtaining the correct result when used to form a forecast of the development of domestic enterprises. 
The study of the dynamics of the company's profits and on this basis, obtaining a forecast for the retrospective assessment of this indicator for the future, allows us to determine the probability of a crisis in the profitability of the enterprise. In the case when the enterprise is unprofitable, it is possible to establish the presence or absence of sources of replenishment of own funds of the enterprise for its normal functioning and development prospects. The main method used at this stage is the calculation of the trend parameters of the company's net profit and the modeling of the main trend of its change. The most accurate forecast can be formed in conditions of a sufficient amount of retrospective sampling. To study the predicted development trend of the enterprise, forecast models were used based on determining the possible dynamics of indicators in the future according to the retrospective trend of actual indicators of the object of study. It should be noted that the period of more than 10 years should be considered necessary and sufficient statistical base (input information). Draw up a calculation table 2 on the performance indicators of the activities of Public Joint-Stock Company «Kremenchug Wheel Plant» (Kremenchug Wheel Plant- machine-building enterprise specialized in the production of wheels) for the period 2002-2017.

Table 2. Calculation of the parameters of the trend equation of the net profit of PJSC «KWP» for the period 2002-2017

\begin{tabular}{|c|c|c|c|c|c|}
\hline 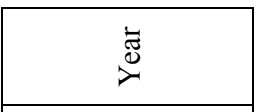 & $\begin{array}{c}\text { Net profit, } \\
\text { thousand UAH. } \\
\text { (Actually) }\end{array}$ & \begin{tabular}{|c|}
$\begin{array}{c}\text { Four quarter } \\
\text { moving } \\
\text { average }\end{array}$ \\
\end{tabular} & $\begin{array}{c}\text { The sum of } \\
\text { two adjacent } \\
\text { values }\end{array}$ & $\begin{array}{c}\text { Centered } \\
\text { average, trend, } \\
\text { thousand UAH }\end{array}$ & $\begin{array}{l}\text { Costs / Trend } \\
\times 100\end{array}$ \\
\hline 2002 & $8,223.5$ & $\mathrm{x}$ & $\mathrm{x}$ & $\mathrm{x}$ & $\mathrm{x}$ \\
\hline 2003 & $9,084.9$ & $\mathrm{x}$ & $\mathrm{x}$ & $\mathrm{x}$ & $\mathrm{x}$ \\
\hline 2004 & $20,812.1$ & $11,487.1$ & $26,663.5$ & $13,331.8$ & 156.1 \\
\hline 2005 & $7,827.8$ & $15,176.4$ & $34,358.1$ & $17,179.0$ & 45.6 \\
\hline 2006 & $22,980.9$ & $19,181.6$ & $39,682.2$ & $19,841.1$ & 115.8 \\
\hline 2007 & $25,105.7$ & $20,500.6$ & $39,313.8$ & $19,656.9$ & 127.7 \\
\hline 2008 & 26,088 & $18,813.2$ & $33,367.1$ & $16,683.5$ & 156.4 \\
\hline 2009 & 1,078 & $14,553.9$ & $27,304.7$ & $13,652.3$ & 7.9 \\
\hline 2010 & 5,944 & $12,750.8$ & $20,908.5$ & $10,454.3$ & 56.9 \\
\hline 2011 & 17,893 & $8,157.8$ & $17,532.0$ & $8,766.0$ & 204.1 \\
\hline 2012 & 7,716 & $9,374.3$ & $23,477.3$ & $11,738.6$ & 65.7 \\
\hline 2013 & 5,944 & $14,103.0$ & $28,026.8$ & $14,013.4$ & 42.4 \\
\hline 2014 & 24,859 & $13,923.8$ & $32,536.8$ & $16,268.4$ & 152.8 \\
\hline 2015 & 17,176 & $18,613.0$ & $41,227.8$ & $20,613.9$ & 83.3 \\
\hline 2016 & 26,473 & $22,614.8$ & $\mathrm{x}$ & $\mathrm{x}$ & $\mathrm{x}$ \\
\hline 2017 & 21,951 & $\mathrm{x}$ & $\mathrm{x}$ & $\mathrm{x}$ & $\mathrm{x}$ \\
\hline Variation & 107.2 & 136.7 & 124.5 & 31.6 & \\
\hline Year & Quarter 1 & Quarter 2 & Quarter 3 & Quarter 4 & \\
\hline 2019 & & & 156.1 & 45.6 & $\mathrm{x}$ \\
\hline 2020 & 115.8 & 127.7 & 156.4 & 7.9 & $\mathrm{x}$ \\
\hline 2021 & 56.9 & 204.1 & 65.7 & 42.4 & $\mathrm{x}$ \\
\hline $\begin{array}{c}\text { Uncorrected } \\
\text { average }\end{array}$ & 108.5 & 138.4 & 126.1 & 32.0 & 404.9 \\
\hline Adjusted average & 107.2 & 136.7 & 124.5 & 31.6 & 400.0 \\
\hline
\end{tabular}

Source: Formed by authors based on [16].

Thus, to study the projected development trend of PJSC «KWP», the data for the period 2002-2017 was used. Additional opportunities for the analyst are generally provided with the assessment of the quality of profits, if for a long period of time stable rates of profit growth are observed, and the share of profits from the main activity prevails in its structure (as is observed within the enterprise PJSC «KWP»), its quality is high. 


\section{Discussion}

Integral assessment of the level of the crisis of the enterprise, as it is proposed for use, should be formed on the basis of a set of financial indicators that allow to fully characterize the state of the enterprise according to the probability of a crisis state for the period of the study and in the future as well. The methodology used combines two components of the assessment - analysis of solvency and its level of profitability.

On the basis of a statistical sample of indicators of industrial enterprises' financial analysis, a linguistic assessment of enterprises' state corresponding to various levels of the development of crisis processes was obtained. According to different levels of the crisis state, the limit values of the indices $K_{\mathrm{ij}}$ Ta $Z_{\mathrm{j}}$ are established (Table 3).

Table 3. Table 3. Limit values for integral indices $Z$

\begin{tabular}{|l|c|}
\hline Financial status & Limit value \\
\hline Deep crisis & $>2.5$ \\
\hline Light crisis & $0.26-2.5$ \\
\hline Sustainable works & $<0.26$ \\
\hline
\end{tabular}

Source: Formed by authors based on [1-3].

A visual representation of the obtained calculation result is an absolute advantage of this technique, while the conditions for establishing the position of the enterprise in crisis zones are made, the choice of priorities of the anti-crisis program of PJSC «KWP» are being made. We will calculate the integral indicator of the assessment of the crisis state of the enterprise using table 4.

Table 4. The calculation of the integral indicator of assessing the crisis state of PJSC «KWP»

\begin{tabular}{|c|c|c|c|c|c|c|c|}
\hline \multirow{3}{*}{ Indicator } & \multicolumn{5}{|c|}{ year } & \multirow{2}{*}{\multicolumn{2}{|c|}{$\begin{array}{l}\text { Calculation procedure } \\
\text { Actual / conditional opt } \\
\text { indicator }\end{array}$}} \\
\hline & \multirow[t]{2}{*}{2014} & \multirow[t]{2}{*}{2015} & \multirow[t]{2}{*}{2016} & \multirow[t]{2}{*}{2017} & \multirow[t]{2}{*}{2018} & & \\
\hline & & & & & & \begin{tabular}{|l|l|l|l|l|}
2014 & 2015 & 2016 & 2017 \\
\end{tabular} & 2018 \\
\hline Current rate of coverage, coeff. $(>\mathbf{2})$ & 1.68 & 2.07 & 1.18 & 1.61 & 1.51 & \begin{tabular}{|l|l|l|l|l|l|l|l|}
0.812 & 1.000 & 0.570 & 0.778 \\
\end{tabular} & 0.729 \\
\hline Autonomy ratio $(>\mathbf{0 . 5})$ & 0.64 & 0.66 & 0.58 & 0.57 & 0.51 & \begin{tabular}{|l|l|l|l|l|}
0.970 & 1.000 & 0.8790 .864 \\
\end{tabular} & 0.773 \\
\hline Absolute liquidity ratio $(>\mathbf{0 . 2})$ & 0.02 & 0.07 & 0.17 & 0.099 & 0.11 & 0.1180 .4121 .0000 .582 & 0.647 \\
\hline $\begin{array}{l}\text { Profitability of operating activities, the } \\
\text { fate of units (max) }\end{array}$ & 6.76 & 15.97 & 10.02 & 11.87 & 8.96 & 70.74 & 0.561 \\
\hline Return on equity, the share of units (max) & 4.4 & 15.05 & 9.55 & 11.84 & 9.8 & \begin{tabular}{|l|l|l|l|}
0.292 & 1.000 & 0.635 & 0.787 \\
\end{tabular} & 0.651 \\
\hline $\begin{array}{l}\text { Net profitability of sales of products (goods } \\
\text { works, services), the fate of units ( } \mathbf{m a x} \text { ) }\end{array}$ & 1.35 & 5.47 & 3.13 & 5.03 & 3.19 & \begin{tabular}{|l|l|l|l|l|l|l|l|l|}
0.247 & 1.000 & 0.572 & 0.920 \\
\end{tabular} & 0.583 \\
\hline $\begin{array}{r}\text { itor of assessing } \\
\sqrt{ }(1-X\end{array}$ & cri & & & & & $0,8090,60$ & 0,859 \\
\hline
\end{tabular}

Source: Formed by the authors on the basis of [16].

One of the ways to solve the problem of predicting the possibility of bankruptcy is also the use of insolvency prediction models developed on the basis of the discriminant analysis method - Z-coefficients. Some of the most well-known approaches to predicting the probability of bankruptcy are systematized in Table 5 .

Summing up the data of an analytical assessment of the probability of bankruptcy, we can conclude that during 2013-2016. The probability of bankruptcy of PJSC «KWP» is low. 


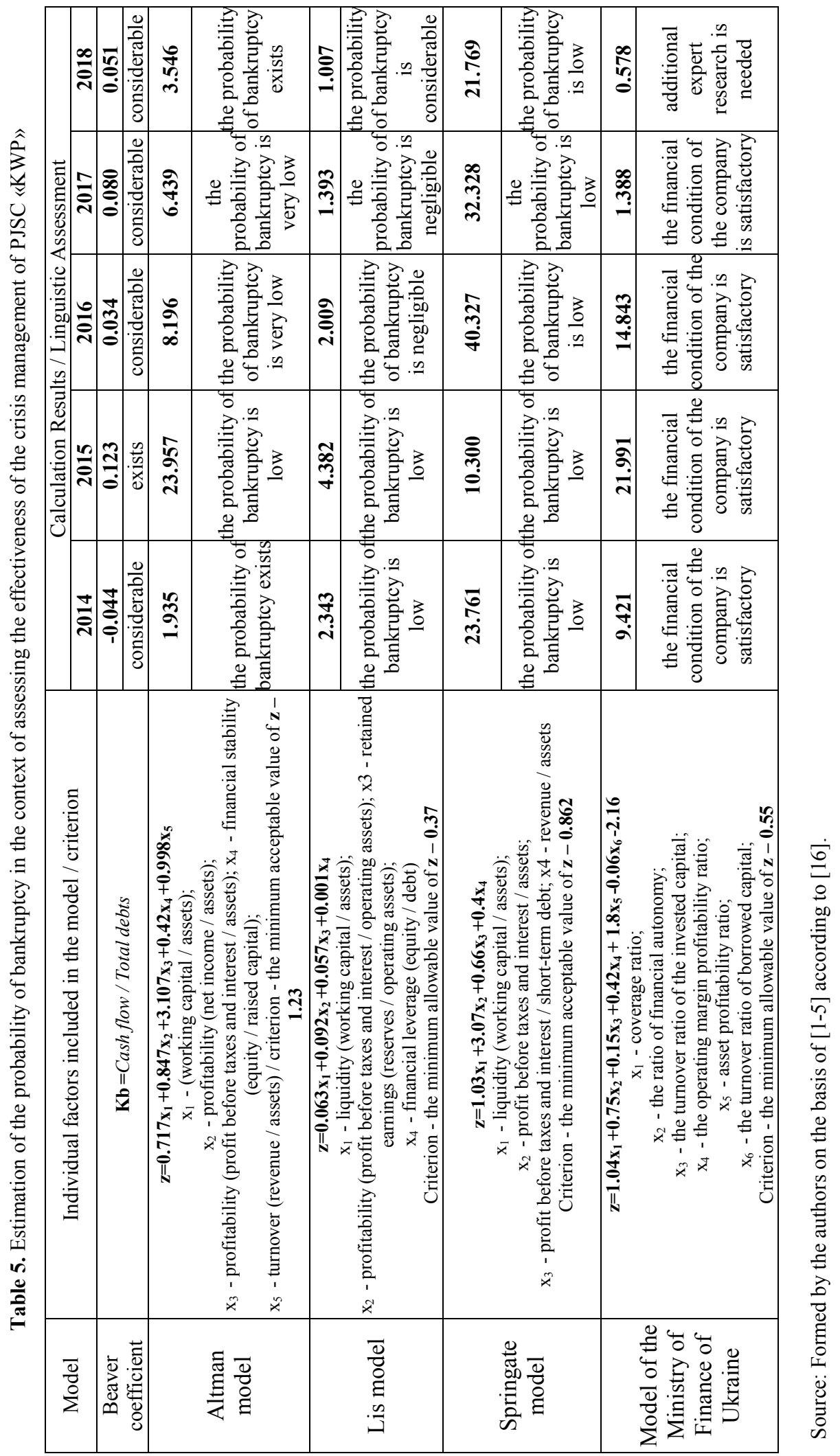


At the same time, one should take into account the emergence of negative dynamics of indicators for the majority of evaluation models at the end of the study period - 2018. At the same time, according to Beaver's diagnostic model, the probability of bankruptcy of an enterprise should be recognized as possible and significant.

Although some authors argue about a sufficient level of predictability of the prospects for the enterprise using Z-coefficients - indicators of the probability of bankruptcy, common in Western countries, it should be pointed out that their use in Ukraine is limited as a result of calculating their weight values of other economic conditions than domestic ones.

Therefore, we supplemented the analysis with the model of the Ministry of Finance of Ukraine, according to calculations for which, at the end of the study period, the state of the enterprise is determined to be doubtful. We will carry out the main trends forecasting in the local indicators that are included in the integral indicator, which we use to calculate the complex indicator for assessing the crisis state of PJSC «KWP». It should be noted that the indicators for assessing the effectiveness of the financial management of the enterprise and the performance of the enterprise, which are internal and relevant, have been selected for consideration.

Trend models allow you to set the forecast values of financial ratios, assess the direction of developments and the priority of financial management measures.

Table 6. Forecasting models of local components of a complex integral indicator for evaluating the effectiveness of a crisis management system

\begin{tabular}{|l|c|c|}
\hline \multicolumn{1}{|c|}{ Local indicators } & Model view & $\begin{array}{c}\text { Coefficient of } \\
\text { determination }\end{array}$ \\
\hline Current rate of coverage, coeff. (>2) & $\begin{array}{c}\mathrm{y}=-0.1854 \mathrm{x}^{4}+2.2875 \mathrm{x}^{3}- \\
9.7296 \mathrm{x}^{2}+16.348 \mathrm{x}-7.04\end{array}$ & $\mathrm{R}^{2}=0.95$ \\
\hline Autonomy ratio (>0.5) & $\begin{array}{c}\mathrm{y}=-0.0121 \mathrm{x}^{4}+0.1492 \mathrm{x}^{3}- \\
0.6429 \mathrm{x}^{2}+1.0858 \mathrm{x}+0.06\end{array}$ & $\mathrm{R}^{2}=0.86$ \\
\hline Absolute liquidity ratio (>0.2) & $\begin{array}{c}\mathrm{y}=0.0198 \mathrm{x}^{4}-0.2343 \mathrm{x}^{3}+ \\
0.9373 \mathrm{x}^{2}-1.4177 \mathrm{x}+0.715\end{array}$ & $\mathrm{R}^{2}=0.78$ \\
\hline $\begin{array}{l}\text { Profitability of operating activities, } \\
\text { the fate of units (max) }\end{array}$ & $\begin{array}{r}\mathrm{y}=-1.48 \mathrm{x}^{4}+18.627 \mathrm{x}^{3}-82.34 \mathrm{x}^{2} \\
+148.04 \mathrm{x}-76.09\end{array}$ & $\mathrm{R}^{2}=0.65$ \\
\hline $\begin{array}{l}\text { Return on equity, the share of units } \\
\text { (max) }\end{array}$ & $\begin{array}{c}\mathrm{y}=-1.5025 \mathrm{x}^{4}+19.015 \mathrm{x}^{3}- \\
84.603 \mathrm{x}^{2}+153.89 \mathrm{x}-82.4\end{array}$ & $\mathrm{R}^{2}=0.88$ \\
\hline $\begin{array}{l}\text { Net profitability of sales of products } \\
\text { (goods, works, services), the fate of } \\
\text { units (max) }\end{array}$ & $\begin{array}{l}\mathrm{y}=-0.7783 \mathrm{x}^{4}+9.5667 \mathrm{x}^{3}- \\
41.172 \mathrm{x}^{2}+72.343 \mathrm{x}-38.61\end{array}$ & $\mathrm{R}^{2}=0.65$ \\
\hline
\end{tabular}

Source: Formed by authors based on [16].

The lack of communication and the adequacy of the model to the experimental data reflect the coefficient of determination. The approximation of this indicator to the unit indicates the accuracy of the model and confirms the possibility of its use for the forecast. At the third stage, a list of targeted anti-crisis measures is developed, which correspond to the peculiarities of the financial condition of the company. We will carry out the ranking of indicators on the basis of the degree of development of negative dynamics and on this basis we will establish the phase of the development of the crisis process. The main requirements for input information in our proposed model are: accessibility, compliance with an integrated assessment approach, completeness.

According to the results of forecasting the dynamics of the coverage ratio for the next period, one should expect its decline, which is negative in the context of strengthening the financial state. 
Forecast on extrapolation of the trend line of the current coverage indicator of PJSC «WWP» (with a forecast of a factor increase of 0,5 points) is presented in the fig. 4.

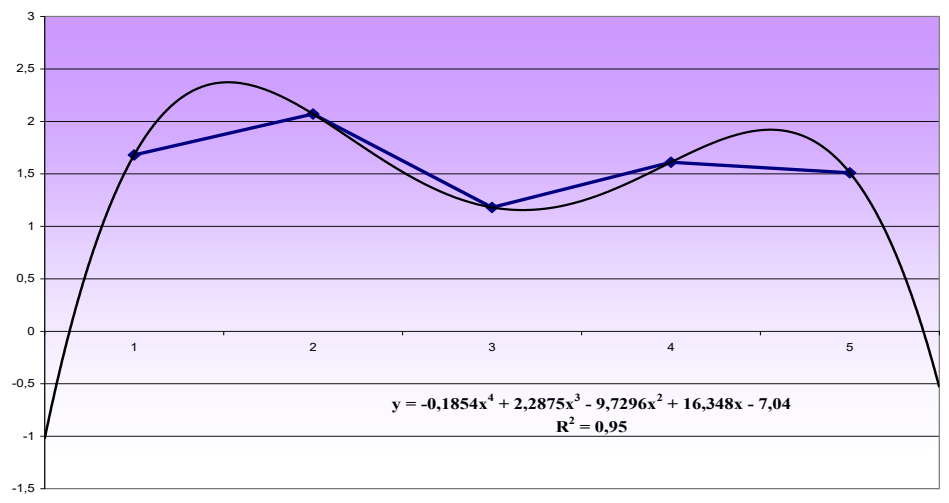

Fig. 4. Forecast on extrapolation of the trend line of the current coverage indicator of PJSC «KWP» (with a forecast of a factor increase of 0,5 points)

Source: Formed by the authors on the basis of [16].

Forecast on extrapolation of the trend line of the autonomy coefficient of PJSC «KWP» (with a forecast of a factor increase of 0,5 points) is presented in the fig. 5 .

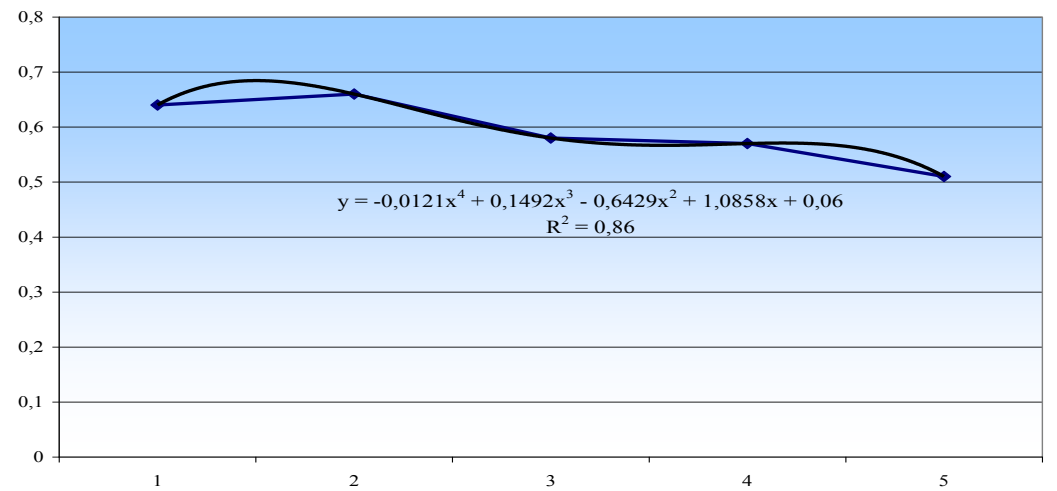

Fig. 5. Forecast on extrapolation of the trend line of the autonomy coefficient of PJSC «KWP» (with a forecast of a factor increase of 0,5 points)

Source: Formed by the authors on the basis of [16].

The forecast for the extrapolation of the trend line of return on equity of PJSC «KWP» (with a forecast of an increase in the factor of 0,5 points) is presented in the fig. 6. 


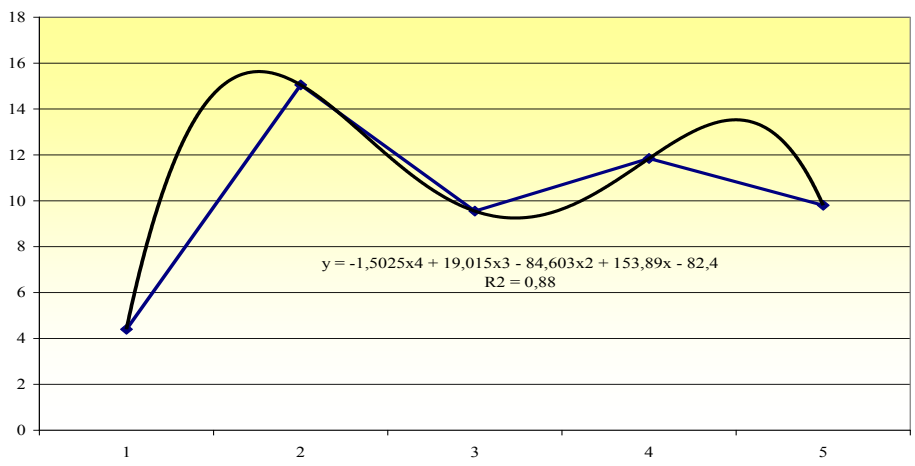

Fig. 6. The forecast for the extrapolation of the trend line of return on equity of PJSC «KWP» (with a forecast of an increase in the factor of 0,5 points)

Source: Formed by the authors on the basis of [16].

Forecast on extrapolation of the trend line of the absolute liquidity ratio of PJSC «KWP» (with a forecast of a factor increase of 0,5 points) is presented in the fig. 7.

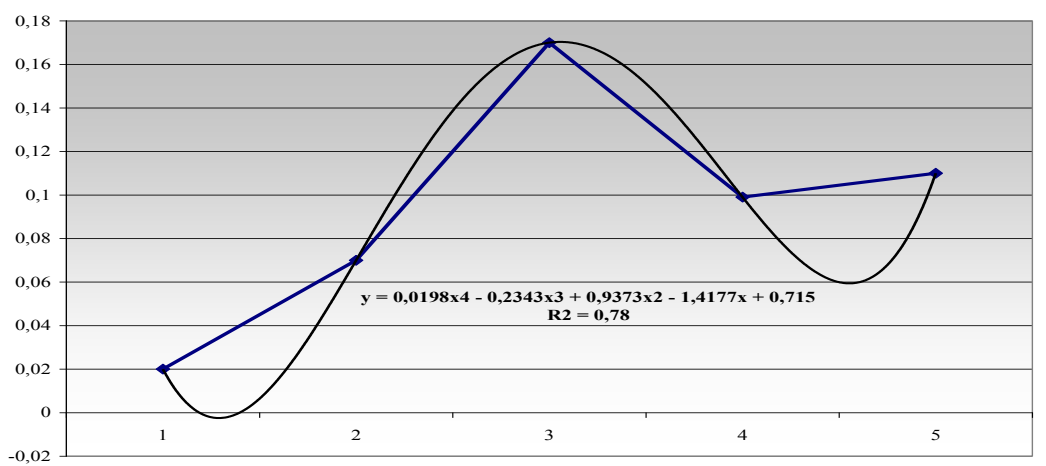

Fig. 7. Forecast on extrapolation of the trend line of the absolute liquidity ratio of PJSC «KWP» (with a forecast of a factor increase of 0,5 points)

Source: Formed by the authors on the basis of [16].

In particular, the last actual value of the indicator is 1.51 , which is $32 \%$ lower than the standard (ordered). The forecast on the extrapolation of the trend line of the local components of the integrated integral indicator for evaluating the effectiveness of the crisis management system of PJSC «KWP» (with a forecast of an increase in the factor of 0,5 points) is illustrated in Fig. 4-7.

The polynomial trend forecast is chosen as the model form, which, compared to the linear dependence, more fully and correctly describes the dynamic changes and the forecast of the local indicator, the results of which are summarized in Table 7. 
Table 7. Forecast values of local indicators for PJSC «KWP»

\begin{tabular}{|c|c|c|c|c|c|}
\hline Period & $\begin{array}{c}\text { Current rate of } \\
\text { coverage, coeff. }\end{array}$ & $\begin{array}{c}\text { Autonomy } \\
\text { ratio }\end{array}$ & $\begin{array}{c}\text { Absolute } \\
\text { liquidity } \\
\text { ratio }\end{array}$ & $\begin{array}{c}\text { Profitability of } \\
\text { operating activities, } \\
\text { the fate of units }\end{array}$ & $\begin{array}{c}\text { Net profitability of } \\
\text { sales of products, the } \\
\text { fate of units }\end{array}$ \\
\hline $\mathbf{0 1 . 0 6 . 2 0 1 9}$ & 1.42 & 0.48 & 0.12 & 8.77 & 3.01 \\
\hline $\mathbf{0 1 . 1 2 . 2 0 2 0}$ & 1.38 & 0.46 & 0.14 & 6.98 & 3.00 \\
\hline
\end{tabular}

Source: Formed by authors based on [16].

The predictive model of the general integral index is constructed as follows:

$$
y=0,102 x^{4}-1,2789 x^{3}+5,683 x^{2}-10,527 x+7,509
$$

The adequacy of the constructed model is confirmed by the values of the correlation and determination coefficients, equal, respectively, 0.98 and 0.96. Based on the calculations, it has been determined that for PJSC «KWP», actions to improve it by strengthening the financial condition and increasing the profitability of production and sales will be successful.

\section{Conclusion}

Thus, the proposed toolkit of methodological support for the action of the anti-crisis program of an industrial enterprise is based on the developed forecast models that will allow evaluating the effectiveness of anti-crisis management both as a whole and individual measures, and is an element of information support for decision-making by lenders to finance the enterprise.

The results show that PJSC «KWP» is in a state of survival or inert existence, and according to the model for assessing the probability of Beaver's bankruptcy, the state is unstable. The increase in the level of competition, the curtailment of the scale of activities of the main consumers of wheeled products led to problems with the sale of the company's products. Ineffective financial management in the context of the formation of a non-optimal structure liability of the enterprise created the conditions for the emergence of the pre-crisis state of the enterprise.

\section{References}

1. G.M. Azarenkova, R.O. Piskunov, M.I. Goikhman, Anticrisis regulation of economic entities cash flow. Kyiv: University of Banking of National Bank of Ukraine, pp. 125127 (2014)

2. O.V. Aref'eva, Anticrisis financial management of enterprise. Lviv: Ukrainian Academy of Printing, pp. $75-79$ (2011)

3. D. Bradley, Ch. Cowdery, Small Business: Causes of Bankruptcy [online], Available at:

http://citeseerx.ist.psu.edu/viewdoc/download?doi=10.1.1.367.4484\&rep=rep1\&type= pdf (2002)

4. D. Bryan, G. Fernando, A. Tripathy, Bankruptcy risk, productivity and firm strategy. Review of Accounting and Finance, 12(4), 309-326 (2013)

5. V.L. Dikan, I.L. Nazarenko, Integrated method for determining the economic security level, risk assessment and probability of enterprises bankruptcy. Kharkiv, Ukrainian State Academy of Railway Transport, pp. 54-80 (2011) 
6. L. Elexa, L. Hvolkova, M. Knapkova, Anticrisis Management: Warning Signals Before Failure. Marketing and Management of Innovations, 3, 98-111 (2019)

7. E. Tobback et al., Bankruptcy prediction for SMEs using relational data. Decision Support System, 102, 69-81 (2017)

8. The State Statistics Service of Ukraine [online], Available at: www.ukrstat.gov.ua/

9. O. Maslak, N. Grishko, K. Vorobiova, O. Hlazunova, The offshorization of economy: the present realities. SHS Web of Conferences: Innovative Economic Symposium 2017 - Strategic Partnership in International Trade, 39 (2017)

10. M. Khomenko, K. Pryakhina, K. Latyshev, Prospects for development of Ukraine and $\mathrm{EU}$ in the field of renewable energy sources. SHS Web of Conferences: Innovative Economic Symposium 2018 - Milestones and Trends of World Economy, 61 (2019)

11. The Global Competitiveness Report 2017-2018 [Online], Available at: http://reports.weforum.org/global-competitiveness-index-2017-2018/at-a-glanceglobal-competitiveness-index-2017-2018-rankings/ (2018)

12. R. Bacik, J. Kloudova, J. Gonos, V. Ivankova, Management of Competitiveness and Economic Performance Based in the V4 Countries. Marketing and Management of Innovations, 3, 73-88 (2019)

13. J. Sebestova, R. Sperka, S. Cemerkova, Determinants of regional business environment in Czech Republic: an expert dilemma. Forum Scientiae Oeconomia, 4(4), 65-74 (2016)

14. E. Bartalosova, Rating of Innovation Performance and Competitiveness of the Visegrad Four in Comparison with the EU Member States. 17th International Scientific Conference on Finance and Risk 2015 (2015)

15. A. Kotaskova, Z. Rozsa, The Impact of Selected Factors on the Quality of Business Environment Assessment in the Czech Republic and the Slovak Republic. International Journal of Entrepreneurial Knowledge, 6(2), 71-80 (2018)

16. Annual financial statements of enterprises, Stock market infrastructure development agency of Ukraine (SMIDA) [online], Available at: http:// www.smida.gov.ua/ (2019) 